\title{
Distribution patterns and nutritional contributions of algal symbionts in the sea anemone Anthopleura xanthogrammica
}

\author{
Michael R. Levine*, Gisèle Muller-Parker
}

Shannon Point Marine Center and Department of Biology, Western Washington University, Anacortes, Washington 98221, USA

\begin{abstract}
The Pacific intertidal sea anemone Anthopleura xanthogrammica hosts 2 algal symbionts, zoochlorellae Elliptochloris marina and zooxanthellae Symbiodinium muscatinei, either alone or co-occurring. Previous studies have suggested that zoochlorellae and zooxanthellae represent 'cool' and 'warm' symbionts with respect to their field distributions, and that these symbionts may differ in their nutritional contributions to their host. We examined the seasonal distribution, density, and growth of these symbionts in A. xanthogrammica tentacles from tidepools and surge channels on the Olympic peninsula in Washington State, USA, measured temperature variation between these microhabitats, and estimated the contributions of zoochlorellae to A. xanthogrammica diet. Tentacles containing dense concentrations of zoochlorellae were found in both tidepools and surge channels at the lower intertidal limit of anemone occurrence. At the upper intertidal limit, tentacles containing primarily zoochlorellae were found in tidepools, and tentacles containing primarily zooxanthellae were found in surge channels. More extreme high temperatures in the upper surge channel may limit the distribution of zoochlorellae and favor a higher proportion of zooxanthellae in this microhabitat. Despite pronounced seasonal fluctuations in temperature, symbiont composition, density, and dietary carbon sources remained remarkably consistent. Stable isotope analysis showed that $A$. xanthogrammica received a greater proportion of dietary carbon from zoochlorellae (62-70\%) than from heterotrophic feeding on Mytilus californianus mussels (31-38\%). This study shows that dense concentrations of zoochlorellae are found in A. xanthogrammica tentacles in cooler microhabitats, and that this symbiont can contribute substantially to anemone nutrition.
\end{abstract}

KEY WORDS: Zoochlorellae $\cdot$ Zooxanthellae $\cdot$ Temperate symbiosis $\cdot$ Anthopleura xanthogrammica

\section{INTRODUCTION}

The intertidal sea anemone Anthopleura xanthogrammica and its congener A. elegantissima host 2 distinct algal symbionts, known as zooxanthellae and zoochlorellae. These anemones have a broad latitudinal distribution along the Pacific coast of North America, ranging from Baja California, Mexico $\left(\sim 30^{\circ} \mathrm{N}\right)$ to southern Alaska, USA $\left(57^{\circ} \mathrm{N}\right.$; Hand 1955). In the northern regions of this range, both zooxanthellae, viz. the dinophyte Symbiodinium muscatinei
(LaJeunesse \& Trench 2000), and zoochlorellae, viz. the green algal chlorophyte Elliptochloris marina (Letsch et al. 2009), co-occur in these anemones. The field distributions of zoochlorellae and zooxanthellae suggest that these represent 'cool' and 'warm' symbionts, respectively, with host anemones containing more zoochlorellae in cooler locations and more zooxanthellae in warmer locations. Studies of $A$. xanthogrammica on Vancouver Island, Canada $\left(48^{\circ} \mathrm{N}\right.$; Bates 2000) and in Coos Bay, Oregon, USA $\left(44^{\circ} \mathrm{N}\right.$; Kitaeff 2007), have shown that zooxanthellae pre- 
dominate at high shore heights, mixed zoochlorellae and zooxanthellae populations are found at intermediate shore heights, and zoochlorellae occur primarily at low shore heights (Bates 2000, Kitaeff 2007). This pattern for $A$. xanthogrammica is also evident on a latitudinal scale, with zooxanthellate anemones found at low latitudes, mixed anemones at intermediate latitudes, and zoochlorellate anemones at high latitudes (Secord \& Augustine 2000, Kitaeff 2007).

Field distributions of symbionts in Anthopleura elegantissima further support a 'cool' and 'warm' symbiont distribution, with this anemone's generally smaller, and therefore warmer (Bingham et al. 2011), body containing more zooxanthellae throughout its range, with an exclusion of zoochlorellae seen at lower latitudes and upper shore heights, than in $A$. xanthogrammica (Secord \& Augustine 2000). In A. elegantissima, algal distributions remain stable seasonally despite considerable variation in aerial temperature and irradiance (Dimond et al. 2011). Field distribution patterns of algal symbionts are also supported by experimental studies of A. xanthogrammica and $A$. elegantissima, which have shown that densities of zoochlorellae increase at cool temperatures $\left(13^{\circ} \mathrm{C}\right)$ and decline at warmer temperatures $\left(20^{\circ} \mathrm{C}\right.$; O'Brien \& Wyttenbach 1980, Saunders \& Muller-Parker 1997).

The distribution of symbionts in these anemone hosts may also be influenced by 'cool' and 'warm' microhabitats within the intertidal zone. Anthopleura xanthogrammica is abundant in tidepools and surge channels (Sebens 1983). For tidepools on Vancouver Island, Bates (2000) observed zooxanthellate A. xanthogrammica closer to the surface and zoochlorellate anemones at lower depths. In that study, cracks and crevices at a given shore height contained more zoochlorellate anemones than tidepools at the same shore height (Bates 2000). Examining anemones in spatially close microhabitats (tidepools and surge channels) experiencing similar emersion times should yield different symbiont populations because of thermal differences in these microhabitats during aerial exposure. If tidepools are the warmer microhabitat on an annual basis, zooxanthellae should predominate in anemones in tidepools and zoochlorellae in anemones in surge channels.

The distribution of zoochlorellae and zooxanthellae within anemones is of interest because the relative contributions of these 2 symbionts to host nutrition may differ with symbiont type, and with microhabitat and season. For Anthopleura elegantissima, carbon budgets of the potential contribution of algal carbon to anemone respiratory carbon consumption have yielded a range of estimated contributions; studies have both estimated lower contributions for zoochlorellae $(9 \%)$ than zooxanthellae $(48 \%$; Verde \& McCloskey 1996) and up to 30 to $50 \%$ higher for zoochlorellae than zooxanthellae (Bergschneider \& Muller-Parker 2008). ${ }^{14} \mathrm{C}$ carbon translocation experiments suggest that zoochlorellae and zooxanthellae each translocate about $30 \%$ of photosynthetically fixed carbon to their host in summer and winter (Engebretson \& Muller-Parker 1999, Bergschneider $\&$ Muller-Parker 2008). However, stable ${ }^{13} \mathrm{C}$ isotope analysis of $A$. elegantissima suggests that heterotrophic food sources are more important to anemone nutrition than the contributions of either symbiont (Bergschneider \& Muller-Parker 2008).

The relative contributions of zooxanthellae and zoochlorellae to the diet of Anthopleura xanthogrammica have not been assessed. Its large body size and consumption of large prey suggest that this anemone may rely on a heterotrophic diet to a greater extent than A. elegantissima. A. xanthogrammica consumes Mytilus californianus mussels that are detached from the rocks by foraging Pisaster ochraceus and by wave action (Sebens 1983), and M. californianus accounts for nearly $70 \%$ of the coelenteron contents of A. xanthogrammica on the outer coast of Washington, USA (Dayton 1973).

In the present study, we hypothesized that intertidal microhabitats differ thermally, and that these differences will influence the symbionts contained within Anthopleura xanthogrammica, with zooxanthellae predominating in warmer habitats and zoochlorellae in cooler habitats. This pattern is hypothesized to remain stable seasonally. Furthermore, we hypothesized that $A$. xanthogrammica has a predominantly heterotrophic diet, regardless of its symbiont complement. Multiple approaches were used to examine these hypotheses: measurement of temperature variation between tidepool and surge channel microhabitats using temperature data loggers, assessment of the seasonal distribution, density, and growth of zoochlorellae and zooxanthellae in A. xanthogrammica tentacles located in these spatially close microhabitats, and estimation of the relative contributions of zoochlorellae and heterotrophic feeding on mussels to A. xanthogrammica using stable ${ }^{13} \mathrm{C}$ and ${ }^{15} \mathrm{~N}$ analysis. This study is also of interest because we investigated the relatively understudied A. xanthogrammica. By examining the factors affecting the prevalence of zoochlorellae in the field, as well as the nutritional contributions of this alga, this study helps to explain the persistence and benefits of zoochlorellae in temperate Anthopleura symbioses. 


\section{MATERIALS AND METHODS}

\section{Field site description}

Slip Point is a rocky outcrop in Clallam Bay on the outer Strait of Juan de Fuca, Washington (USA), with exposures ranging from northwest to northeast. Within Slip Point, a north facing outcrop known as Submarine Rock $\left(48^{\circ} 15^{\prime} 50^{\prime \prime} \mathrm{N}, 124^{\circ} 14^{\prime} 143^{\prime \prime} \mathrm{W}\right)$ was selected for sampling due to its relative inaccessibility, diversity of microhabitats, and abundance of Anthopleura xanthogrammica. The distribution of A. xanthogrammica at the site has an upper vertical tidal limit in tidepools of $+1.59 \mathrm{~m}$ in relation to Mean Lower Low Water (MLLW; all subsequent tidal heights are reported in reference to MLLW). The anemones' lower limit of distribution is subtidal. Extensive beds of the mussel Mytilus californianus and gooseneck barnacle Pollicipes polymerus are also present, indicative of considerable wave exposure at the site.

\section{Microhabitat temperature monitoring}

HOBO temperature data loggers $\left( \pm 0.2^{\circ} \mathrm{C}\right.$ accuracy; Onset Computer Corporation U22 Water Temp Pro model) were anchored in a tidepool $(+1.59 \mathrm{~m}$ shore height, $2.75 \mathrm{~m}^{3}$ volume, $38 \mathrm{~cm}$ maximum depth) and at the bottom of a surge channel $(+1.19 \mathrm{~m})$ to record temperatures at $10 \mathrm{~min}$ intervals. The tidepool data logger recorded from 31 July 2008 to 10 April 2009. Due to data logger damage, the surge channel logger recorded from 30 August to 13 November 2008 and from 13 April to 19 June 2009. Because of the need to select suitable locations for anchoring the data loggers, resulting in tidal height differences, immersion times of data loggers differed between these locations, with the surge channel data logger emersed for less time than the tidepool (approximately $49 \%$ and $69 \%$ annually, as judged from Clallam Bay tide datum July 2008 to July 2009). Tidal heights were measured using a stadia rod sighted with standard surveying transit. Heights measured on the stadia rod were referenced to known tidal levels using a Clallam Bay tide chart with 15 min tide intervals (Nobeltec Tides and Currents software, 2006). Plastic zip-ties were used to attach data loggers to stainless steel eyebolts embedded in ZSPAR splash zone epoxy (RPM). Temperature data obtained for each day were summarized by calculating the average temperature and recording the daily maximum and minimum temperatures. These were used to calcu- late the monthly average and the average daily maximum and minimum temperatures. Daily average seawater temperatures were calculated from temperatures obtained when data loggers were submerged by the high tide. These values were used as a reference baseline for comparing temperatures recorded in tidepools and surge channels, with the range above or below the daily seawater temperature indicating thermal change in each microhabitat during low tide exposures to air.

\section{Anemone selection, tentacle sampling, and mussel sampling}

Anthopleura xanthogrammica was clustered in tidepools and on the floors of surge channels, in close proximity to Mytilus californianus beds. To reflect this distribution, we chose sampling sites consisting of paired tidepool and surge channel microhabitats in close proximity and at similar shore height. Based on the observed vertical distribution of anemones, individuals located at tidal heights above $+1.07 \mathrm{~m}$ were designated high intertidal, and those below $+0.61 \mathrm{~m}$ were designated low intertidal. Anemones were selected randomly (by using a random number table to select positions along a transect tape spanning the longest axis of the microhabitat) or haphazardly (by selecting anemones that were positioned along this axis by chance) from 4 tidepools and 2 surge channels. The high and low intertidal sites each contained 2 tidepools and 1 surge channel. Tidepools had an average volume of $2.56 \pm 1.02 \mathrm{~m}^{3}$ (all values are reported as mean $\pm \mathrm{SE}$ ), as determined by the average depth and maximum width of each pool.

Tentacle samples were taken from selected anemones in summer ( 30 to 31 July 2008), fall (13 November 2008), and spring (10 to 11 April 2009) seasons (for sample sizes in each season and microhabitat, see Fig. 3). After photographing the individual anemones, scissors were used to remove about 6 tentacles from each anemone. Tentacles were sampled because tentacles contain the highest density of algae within Anthopleura xanthogrammica (Kitaeff 2007), and their removal is non-lethal and repeatable. Tentacles were stored on ice in the field and in transit (for approximately 3 to $6 \mathrm{~h}$ ), quickly moved to a standard freezer, and subsequently stored at $-70^{\circ} \mathrm{C}$ prior to analysis. After sampling tentacles, Vernier calipers ( $\pm 0.1 \mathrm{~mm}$ precision) were used to measure the body column diameter at the base to the nearest $\mathrm{mm}$.

We sampled 45 anemones in summer 2008 and spring 2009 (anemone body column diameter 
$110.78 \pm 5.18 \mathrm{~mm}$ in summer; $110.16 \pm 5.28 \mathrm{~mm}$ in spring). Due to anemone contraction behavior during low tides at night when air temperatures were very low, only 20 anemones were sampled in fall 2008 (anemone body column diameter $102.53 \pm 8.98 \mathrm{~mm}$ ), resulting in limited power to interpret trends during this season (for sample sizes, see Fig. 3).

During the initial sampling in the summer of 2008, reference marks consisting of ZSPAR splash zone epoxy or photographs, anemone locations along transect tapes, and numbered photographs of each sampled anemone were taken to aid in identifying anemones for later re-sampling. Anemones that were re-identified were then confirmed using body column diameter measurements. New individuals were selected for sampling if anemones were missing or if individuals could not be identified with confidence.

Mytilus californianus was haphazardly collected for stable isotope analysis. Individuals were collected in summer (31 July 2008) and spring (11 April 2009). Mussels were taken from the edges of each of 3 tidepools and from each of 2 surge channels ( $\mathrm{n}=8$ summer; $\mathrm{n}=10$ spring) (see Fig. 2, Table 2). Mussels were placed in a bucket filled with approximately 51 of $5 \mu \mathrm{m}$ filtered seawater for $24 \mathrm{~h}$ to evacuate their gut contents. Mussels were kept in a standard freezer immediately following gut evacuation and kept on ice during transit (approximately $6 \mathrm{~h}$ ) until they could be stored at $-70^{\circ} \mathrm{C}$.

\section{Tentacle sample processing}

Tentacle samples from individual anemones collected in summer 2008 and spring 2009 were divided into 2; half were analyzed for biomass parameters (algal cell density, algal mitotic index, and anemone protein content), and the other half were used for ${ }^{13} \mathrm{C}$ and ${ }^{15} \mathrm{~N}$ stable isotopic analysis. To split samples, half of the tentacles were haphazardly selected and removed with a metal spatula immediately prior to biomass parameter analysis, and the remainder were immediately re-frozen. Tentacle samples collected in fall 2008 were analyzed only for biomass parameters.

Thawed tentacles were placed on Parafilm ${ }^{\circledR}$ squares, visually inspected, and any debris removed using tweezers before processing. For biomass parameters, tentacles were homogenized in a small volume of $5 \mu \mathrm{m}$ filtered seawater using a $3 \mathrm{ml}$ tapered glass tissue homogenizer and Teflon pestle (Wheaton Science Products) attached to a motorized overhead stirrer (Wheaton Science Products). Samples were kept on ice during homogenization. Each homogenate sample was mixed by vortexing, dispensed into two $1.5 \mathrm{ml}$ microfuge tubes, and stored at $-70^{\circ} \mathrm{C}$ prior to analysis. Prior to algal cell density and mitotic index enumeration, thawed homogenate samples were mixed by vortexing, and a hemocytometer slide (Brightline, Reichert Scientific Instruments) was used to count algae.

\section{Algal cell density}

Both zooxanthellae and zoochlorellae were counted until at least 100 cells of the most abundant algal type were enumerated, using a compound microscope at $400 \times$ magnification, or $100 \times$ in the case of especially dilute samples. Four replicate counts were made for each sample, and average densities of zooxanthellae and zoochlorellae (cells $\mathrm{ml}^{-1}$ ) were calculated.

To compare algal densities in tentacles, the numbers of zooxanthellae and zoochlorellae per unit weight of homogenate protein were obtained for each sample. Protein concentration was measured using the method of Lowry et al. (1951) using bovine serum albumin as a protein standard (Pierce). Algal densities were calculated by dividing the concentration of each alga by the concentration of homogenate protein. Although total homogenate samples (containing both algae and anemone tissue) were used to measure anemone protein, intact algae do not contribute significantly to the protein values obtained (Verde \& McCloskey 2001, G. Muller-Parker pers. obs.), and homogenate protein concentrations are considered representative of the anemone (= animal) component.

\section{Algal mitotic index}

The mitotic index, an estimate of symbiont growth defined as the number of algal cells dividing at the time of sampling, was calculated for the most abundant symbiont in each sample, defined as the alga that comprised over half of the algal cells within a sample. Cells with a complete cleavage furrow were scored as dividing, as judged using a compound microscope at 400× magnification. One thousand zooxanthellae or zoochlorellae were counted, and mitotic index was expressed as the percent of dividing zooxanthellae or zoochlorellae. In 2 very low algal density samples, only 500 algae were counted. 


\section{Statistical analysis of algal composition, density, and mitotic index}

One-way analysis of variance (ANOVA) tests were used to determine whether microhabitat affected algal density within anemone tentacles, the mitotic index of zooxanthellae and zoochlorellae within tentacles, and the relative proportions of zoochlorellae and zooxanthellae in tentacles. Four levels of microhabitat were examined: low tidepool, low surge channel, high tidepool, and high surge channel. The low and high tidepool microhabitats each contain data from 2 tidepools that were pooled a priori. Significant ANOVA tests were followed by pairwise comparisons between microhabitats using Tukey's HSD tests (algal density and mitotic index) or simple contrasts between the high surge channel and high tidepool microhabitats (percent zoochlorellae in tentacles within a microhabitat). To examine changes in algal density and mitotic index of zooxanthellae and zoochlorellae over the entire study period, the subset of anemones sampled both in summer 2008 and spring 2009 were analyzed with repeated measures ANOVA.

All data were checked for homogeneity of variances prior to analysis. Data were square-root transformed in cases where homogeneity of variances was violated (judged with Levene's test). All percentage values were arcsine transformed prior to analysis (Sokal \& Rohlf 1969). A significance criterion of $\alpha=0.05$ was used for all comparisons meeting the assumption of homogeneity of variances. In cases where this assumption could not be met through transformation of the data, significance was adjusted to $\alpha=0.025$ (Underwood 1981). All statistical analyses were performed using SPSS v.15.0. Significant ANOVA tests were followed by pairwise comparisons among microhabitats using Tukey's HSD tests.

\section{Preparation of tentacle and mussel samples for stable isotope analysis}

Because the salt content of seawater influences sample weights (Pitt et al. 2009), tentacles for stable isotope analysis were homogenized, as previously described, in Nanopure ${ }^{\circledR}$ water. Homogenate samples were mixed by vortexing, placed into two $1.5 \mathrm{ml}$ microfuge tubes and stored at $-70^{\circ} \mathrm{C}$ prior to further processing. All equipment in contact with samples (homogenizer, pestle, and spatulas) was cleaned with 3 rinses of methanol followed by 3 tap water rinses and 3 Nanopure ${ }^{\circledR}$ water rinses before use, and in between each sample.

Thawed homogenates were centrifuged at $1118 \times g$ (4 min; Eppendorf microfuge) to separate algae and anemone fractions. The anemone (= animal) supernatant was decanted into a $20 \mathrm{ml}$ glass scintillation vial, and the algal pellet was resuspended in $1 \mathrm{ml}$ of water. Three centrifugation and resupension cycles were completed, resulting in 1 anemone fraction and 1 algal fraction from each homogenate. The final algal suspension was filtered sequentially through $63 \mu \mathrm{m}$ and $30 \mu \mathrm{m}$ Nitex mesh screens to remove clumps of anemone tissue. Anemone and algal fractions were stored at $-70^{\circ} \mathrm{C}$ prior to being freeze-dried for $24 \mathrm{~h}$ using a VirTis Freezmobile freeze dryer. Based on algal populations in the samples, anemone tentacles were classified as zoochlorellate (containing $\geq 90 \%$ zoochlorellae prior to separation), mixed zoochlorellate (containing 50-90\% zoochlorellae), mixed zooxanthellate (containing $50-90 \%$ zooxanthellae), and zooxanthellate (containing $\geq 90 \%$ zooxanthellae); the same categories were applied to the separated algal fractions.

Mytilus californianus posterior adductor muscle, a tissue that integrates the carbon and nitrogen isotopic signatures of mussel food sources over relatively long time scales (Gorokhova \& Hansson 1999), was thawed, cleaned of attached viscera, rinsed with Nanopure ${ }^{\circledR}$ water, placed in a $20 \mathrm{ml}$ glass scintillation vial, and stored at $-70{ }^{\circ} \mathrm{C}$ prior to freeze drying. All tools used in dissection (scalpel, scissors, forceps, and dissecting pan) were cleaned using the protocol described above for tentacle homogenization.

After freeze drying, anemone and algal samples were homogenized to a fine powder in microfuge tubes using pointed metal spatulas. Mussel tissue was ground in a methanol-rinsed mortar and pestle to a fine powder. All samples were encapsulated in tin capsules (Costech Analytical Technologies) and shipped to the University of California Davis Stable Isotope Facility for flow-through mass spectrometric analysis. Values are reported using $\delta$ notation, which is the parts per thousand (\%o) deviation of the sample ${ }^{13} \mathrm{C} /{ }^{12} \mathrm{C}$ or ${ }^{15} \mathrm{~N} /{ }^{14} \mathrm{~N}$ ratio from that of accepted standards (Peterson \& Fry 1987).

Prior to dietary analysis, algal isotopic samples were checked for potential contamination with host anemone tissue. During separation of symbionts from host anemone tissue, the homogenized host tissue forms a supernatant after centrifugation that is unlikely to contain pelleted algal cells. However, the algal pellet, despite filtration through the Nitex mesh screens to remove clumps, may contain remnant host 
tissues in addition to symbionts. To assess potential contamination, any $\delta^{15} \mathrm{~N}$ values for algae that were equal to or higher than mean host tissue values for $\delta^{15} \mathrm{~N}$ were excluded from the dietary analysis. These samples could indicate anemone tissue contamination because the $\delta^{15} \mathrm{~N}$ signature gets progressively 'heavier' as it moves up trophic levels, increasing by about 2.3\% per level (McCutchan et al. 2003). In addition, microscopic inspection of the isolated zoochlorellae and mixed zoochlorellae algal assemblages revealed slight contamination with host tissue, while zooxanthellae and mixed zooxanthellae were more heavily contaminated with animal particles.

To examine the relative contributions of symbiotic algae and Mytilus californianus to host anemone carbon composition, the partitioning of carbon isotopes was examined using the Isoerror 2-source mixing model (all equations and accompanying Excel spreadsheet in Phillips \& Gregg 2001). The model was used to calculate the proportion of host carbon derived from each source (symbiotic algae and $M$. californianus) using the $\delta^{13} \mathrm{C}$ values of each component. Prior to addition to the model, dietary sources were corrected for carbon fractionation of $0.4 \%$ per trophic level, which is the average for aquatic systems provided in a recent review by McCutchan et al. (2003).

\section{RESULTS}

\section{Temperature monitoring}

In both microhabitats, the intertidal zone at Slip Point experienced annual variation in temperatures spanning over $25^{\circ} \mathrm{C}$. During emersion, temperatures recorded in the tidepool ranged from a low of $-0.7^{\circ} \mathrm{C}$ in December 2008 to a high of $24.4^{\circ} \mathrm{C}$ in August 2008, and temperatures recorded in the surge channel ranged from a low of $3.5^{\circ} \mathrm{C}$ in November 2008 to a high of $30.6^{\circ} \mathrm{C}$ in May 2009. Average daily temperatures (comprising both immersion and emersion periods) were highest in the tidepool in August 2008 $\left(16.3 \pm 0.54^{\circ} \mathrm{C}, \mathrm{n}=31\right)$ and lowest in December 2008 $\left(4.8 \pm 0.48^{\circ} \mathrm{C}, \mathrm{n}=31\right.$; Fig. 1a). Average daily temperatures in the surge channel were highest in June $2009\left(23.6 \pm 0.82^{\circ} \mathrm{C}, \mathrm{n}=18\right)$ and lowest in October $2008\left(6.5 \pm 0.31^{\circ} \mathrm{C}, \mathrm{n}=31\right.$; Fig. 1). It is important to note that tidepool and surge channel measurements were not always recorded at the same time due to data logger loss, so while averages and extremes are indicative of each microhabitat, they are not directly comparable.

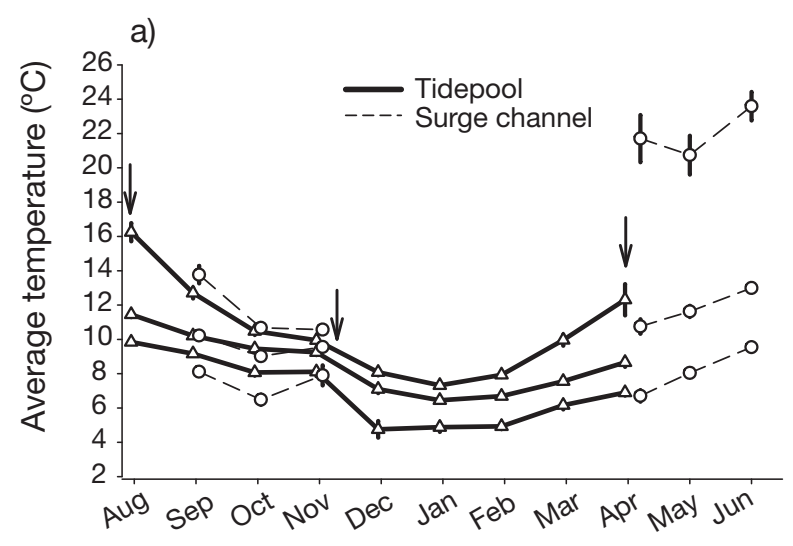

b)

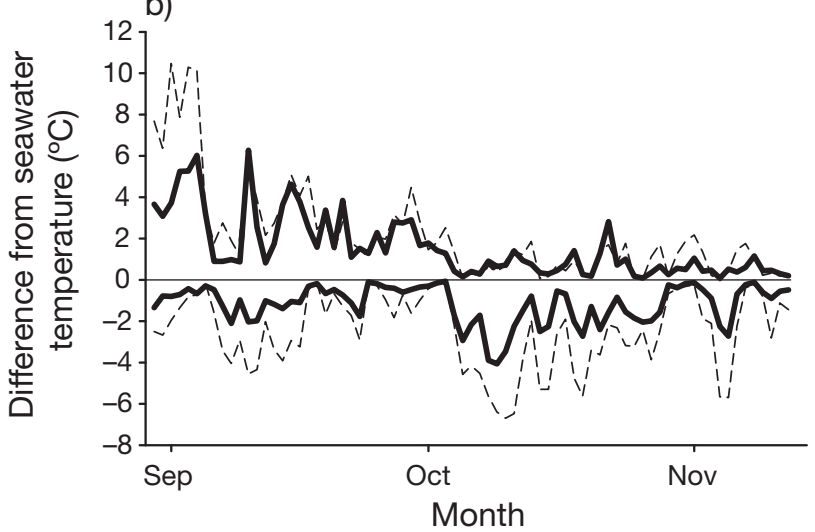

Fig. 1. (a) Monthly temperatures $( \pm \mathrm{SE}$ ) in a tidepool (+1.59 m Mean Lower Low Water, MLLW) and a surge channel (+1.19 m MLLW) at Slip Point, Clallam Bay, Washington, USA. Uppermost lines represent average monthly high, middle lines represent average, and low lines represent average monthly low temperature within each microhabitat. Standard errors are an estimate of within-month variation. Arrows indicate anemone tentacle sampling dates. Note that measurements were not always available at the same time due to data logger loss. (b) Difference above (positive values) and below (negative values) daily seawater temperature in the same tidepool and surge channel from 31 August to 12 November 2008

When both data loggers were recording at the same time, the surge channel microhabitat yielded more extreme high and low temperatures (Fig. 1b). On a relatively warm day (1 September 2008), the surge channel reached $10.5^{\circ} \mathrm{C}$ above the daily seawater temperature, while the tidepool temperature increased only by $3.7^{\circ} \mathrm{C}$ relative to seawater. On a relatively cold day (11 October 2008), temperatures in the surge channel dropped $6.5^{\circ} \mathrm{C}$ relative to seawater, while tidepool temperatures only dropped $2.3^{\circ} \mathrm{C}$ (Fig. 1b). This is reflected in monthly average temperature excursions during emersion when both data loggers were simultaneously recording. In October 2008, low temperature excursions in the surge channel averaged $3.3 \pm 0.36^{\circ} \mathrm{C}(\mathrm{n}=31)$ below seawa- 
ter temperature, and were $1.6^{\circ} \mathrm{C}$ lower than the mean daily departure from seawater temperature in the tidepool (paired $t$-test, $t=8.00$, df $=30, \mathrm{p}<0.001$ ). In September 2008, low temperature excursions in the surge channel $(\mathrm{n}=30)$ averaged $1.0^{\circ} \mathrm{C}$ lower than in the tidepool with respect to ambient seawater temperature (paired $t$-test, $t=6.97, \mathrm{df}=30, \mathrm{p}<0.001$ ). The surge channel also experienced significantly higher excursions in temperature in September than the tidepool, averaging $1.1^{\circ} \mathrm{C}$ higher on a daily basis (paired $t$-test, $t=-3.67, \mathrm{df}=30, \mathrm{p}=0.001$ ).

\section{Distribution, algal density, and mitotic index of symbionts in tentacles of Anthopleura xanthogrammica}

Irrespective of microhabitat or season, zoochlorellae were the predominant symbionts within Anthopleura xanthogrammica tentacles at Slip Point, with
$63 \%$ of anemone tentacle samples containing $\geq 90 \%$ zoochlorellae, and $7 \%$ containing $\geq 90 \%$ zooxanthellae $(n=110)$. Mixed algal assemblages of between 10 and $90 \%$ of 1 alga were found in $29 \%$ of anemone tentacles, with the majority $(75 \%)$ of these mixed assemblages comprised of $\geq 50 \%$ zoochlorellae.

The distribution of zoochlorellae and zooxanthellae in Anthopleura xanthogrammica tentacles at Slip Point corresponded with the temperature patterns obtained in both microhabitats. High numbers of zoochlorellae were found in anemone tentacles in the cooler low tidepool and low surge channel habitats, mixed algal populations containing primarily zoochlorellae were found in tentacles from anemones in the moderately cooler high tidepool microhabitats, and mixed algae containing primarily zooxanthellae were found in tentacles of anemones in the surge channel experiencing more extreme high temperatures at high tidal heights (Fig. 2a-d). This distribution pattern remained stable across all seasons. a) High tidepool

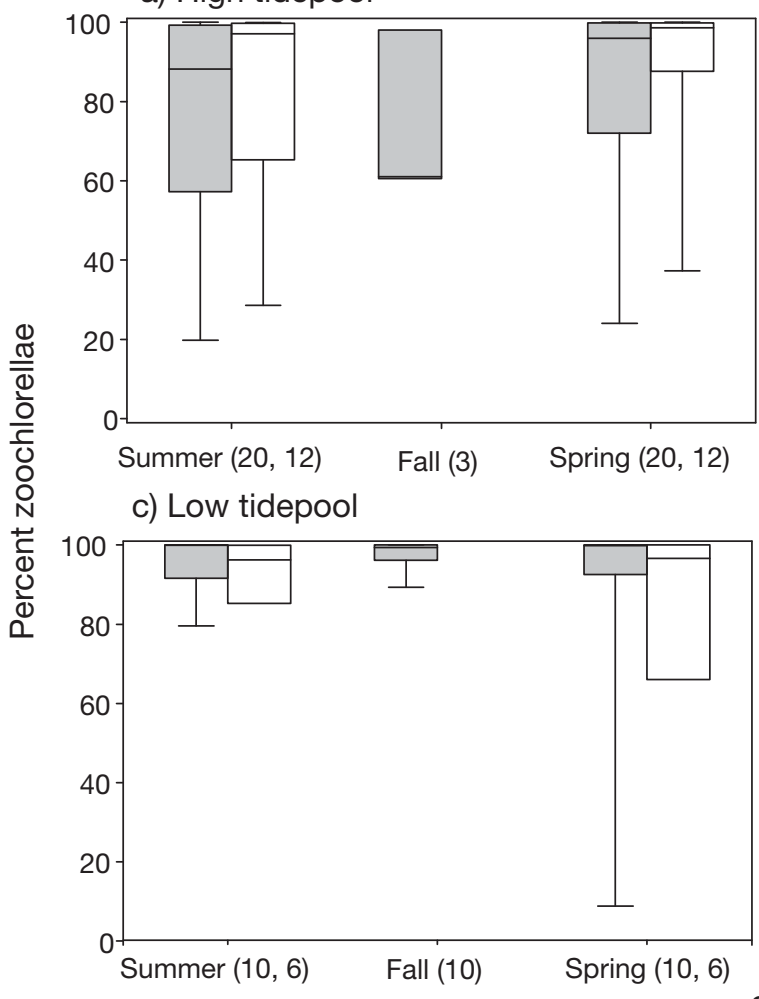

b) High surge channel

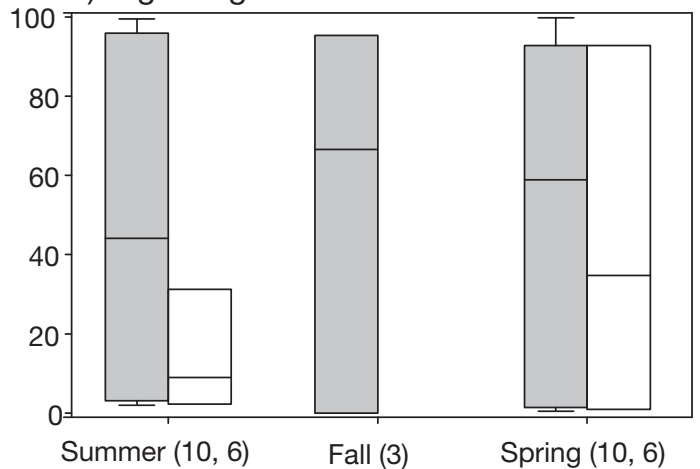

d) Low surge channel

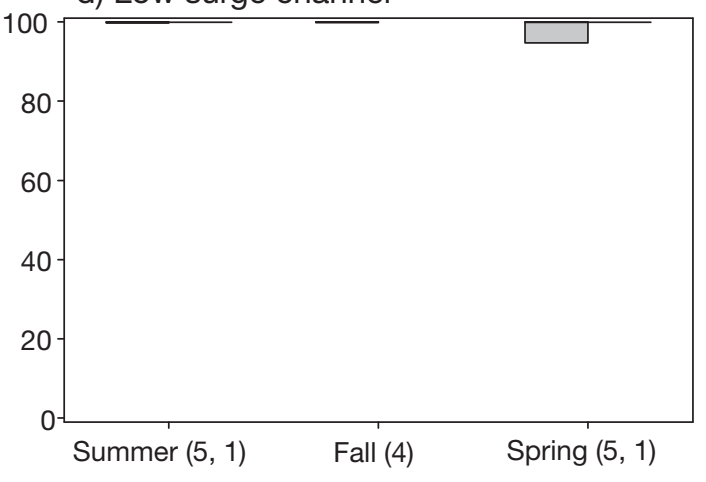

Fig. 2. Percentage of zoochlorellae in algal populations in Anthopleura xanthogrammica tentacles in (a) high tidepool, (b) high surge channel, (c) low tidepool, and (d) low surge channel microhabitats. Grey boxplots represent all anemones from each seasonal sampling; white boxplots in summer and spring represent the subset of anemones sampled repeatedly across seasons. The black line within a boxplot represents the median percent zoochlorellae for percentiles $<99 \%$, areas below and above the median represent the 25th percentile and 75th percentiles, and lines below and above boxes represent the 10th and 90th percentiles, respectively. The 10th and 90th percentiles were calculated when $n \geq 9$. Sample sizes are in parentheses; the first number represents anemones from each seasonal sampling, the second represents the anemones sampled across seasons 
There was great variation in the distribution of algal symbionts in anemones in the high surge channel microhabitat; tentacles of these anemones ranged from nearly $100 \%$ zoochlorellae to nearly $100 \%$ zooxanthellae (Fig. 2b). Anemone tentacles from high surge channels (summer 2009, $\mathrm{n}=10$; spring 2010, $\mathrm{n}=10$ ) contained a significantly lower proportion of zoochlorellae than tentacles from anemones in the high tidepools in summer $2008(\mathrm{n}=20)$ and spring $2009(\mathrm{n}=20)$ seasons (summer, $\mathrm{p}=0.015$; spring, $\mathrm{p}=$ 0.023 ; $\alpha$ adjusted to 0.025 ).

Algal density patterns in summer and spring seasons support the algal distribution patterns among microhabitats. In these seasons, anemone tentacles from the high surge channel microhabitat contained significantly lower densities of zoochlorellae than tentacles from all other microhabitats (Fig. $3 \mathrm{a}-\mathrm{c}$ ). In summer, tentacles from high surge channel anemones $(\mathrm{n}=10)$ contained $0.317 \times 10^{6} \pm 0.132 \times 10^{6}$ zoochlorellae per mg tentacle protein, a significantly lower density of zoochlorellae than obtained for anemone tentacles from the high tidepool $(1.75 \times$ $10^{6} \pm 0.422 \times 10^{6}, \mathrm{p}=0.015, \mathrm{n}=20$ ), low surge channel $\left(3.00 \times 10^{6} \pm 0.461 \times 10^{6}, \mathrm{p}=0.001, \mathrm{n}=5\right)$, and low tidepool $\left(3.63 \times 10^{6} \pm 0.740 \times 10^{6}, \mathrm{p}<0.001, \mathrm{n}=10\right)$ microhabitats. Tentacles in the high tidepool microhabitat also contained a significantly lower density of zoochlorellae than those from the low tidepool $(\mathrm{p}=$ 0.015). In spring, anemone tentacles in the high surge channel $\left(0.276 \times 10^{6} \pm 0.152 \times 10^{6}\right.$ zoochlorellae $\mathrm{mg}^{-1}$ tentacle protein, $\mathrm{n}=10$ ) contained a significantly lower density of zoochlorellae than anemone tentacles in the high tidepool $\left(1.14 \times 10^{6} \pm 0.203\right.$ $\left.\times 10^{6}, \mathrm{p}=0.010, \mathrm{n}=20\right)$, low surge channel $(2.47 \times$ $10^{6} \pm 0.303 \times 10^{6}, \mathrm{p}=0.013, \mathrm{n}=5$ ), and low tidepool $\left(1.55 \times 10^{6} \pm 0.416 \times 10^{6}\right.$, $\mathrm{p}=0.004, \mathrm{n}=10)$ microhabitats, which did not differ significantly from each other in algal density (Tukey HSD comparisons, all $\mathrm{p}>0.05$ ).

In contrast to the summer and spring seasons, the proportion and density of zoochlorellae in anemone tentacles sampled in fall 2008 (Figs. 2a-d \& $3 \mathrm{~b}, \mathrm{e})$ did not differ significantly between the high surge channel $(\mathrm{n}=3)$ and high tidepool $(\mathrm{n}=3$; proportion of zoochlorellae, $\mathrm{p}=0.207$; density of zoochlorellae, $\mathrm{p}=0.289$ ). However, low sample sizes in this season severely limited the ability to detect trends between microhabitats, and patterns appeared qualitatively similar to those in summer and spring seasons.

Seventeen of the anemones sampled in fall were confirmed as re-samples from the summer sampling. In spring 2009, 25 anemones were confirmed as re-samples from summer. In these anemones, there was a trend toward a decreasing density of zoochlorellae between summer 2008 and spring 2009 in low tidepool and low surge channel anemone tentacles, with zoochlorellae in tentacles of anemones in these microhabitats declining approximately 57 and $52 \%$, respectively, over this time period (Fig. 3a-c). This trend was not supported among anemones sampled both in summer 2008

Fig. 3. Average $( \pm \mathrm{SE})$ seasonal densities of $(\mathrm{a}-\mathrm{c})$ zoochlorellae and $(\mathrm{d}-\mathrm{f}) \mathrm{zoo-}$ xanthellae in Anthopleura xanthogrammica tentacles from low tidepool (LTP), low surge channel (LSC), high tidepool (HTP), and high surge channel (HSC) microhabitats. Numbers above bars indicate sample size; different letters within a season and symbiont type indicate significant difference between microhabitats at $\mathrm{p}<0.05$. NS: no significant difference in algal densities between any microhabitat within a season 
and spring 2009 (repeated measures ANOVA, p = $0.084, \mathrm{n}=25)$.

In contrast to the distinct patterns observed in the density of zoochlorellae among microhabitats and tidal heights, the density of zooxanthellae in anemone tentacles was consistently low in all microhabitats, and was often an order of magnitude lower than that of zoochlorellae regardless of season (Fig. 3d-f). The density of zooxanthellae did not vary seasonally among microhabitats except during fall 2008 (1-way ANOVA, $\mathrm{p}=0.008, \mathrm{n}=20$ ), when tentacles from anemones in the high tidepool $(n=3)$ contained significantly higher numbers of zooxanthellae than those from anemones in the low tidepool $(\mathrm{p}=0.032$, $\mathrm{n}=10)$ and low surge channel $(\mathrm{p}=0.014, \mathrm{n}=4)$.

The mitotic index (MI) of zoochlorellae did not differ in anemone tentacles collected from the high surge channel and high tidepool microhabitats (Fig. 4a-c). In summer 2008, the MI of zoochlorellae in tentacles of anemones in the high surge channel ( $\mathrm{n}=4)$ was $8.78 \pm 1.77 \%$, less than half that of zoochlorellae from anemones in the low surge channel $(16.82 \pm 0.99 \%$; $\mathrm{p}=0.006, \mathrm{n}=5)$ and the low tidepool $(18.28 \pm 0.87 \% ; \mathrm{p}<0.001, \mathrm{n}=10)$ microhabitats. In fall 2008, zoochlorellae in high tidepool anemone tentacles ( $\mathrm{n}=2$ ) had an MI of $9.72 \pm 1.88 \%$, significantly lower than the MI of zoochlorellae in tentacles from the low tidepool $(\mathrm{n}=10)$ and low surge channel ( $\mathrm{n}=4$; contrast of high tidepool versus low tidepool and low surge channel, $\mathrm{p}=$ 0.001). The only high surge channel anemone with zoochlorellate tentacles sampled in fall 2008 had an MI of $15.40 \%$; this small sample did not allow trends in the high surge channel to be examined. There were no significant differences in MI of zoochlorellae among microhabitats in spring 2009 (1-way ANOVA, $\mathrm{p}=0.175, \mathrm{n}=35$ ). Seasonally, the MI of zoochlorellae across all microhabitats was highest in fall $2008(19.74 \pm 1.43 \%, \mathrm{n}=17)$, intermediate in summer $2008(14.12 \pm 0.77 \%, \mathrm{n}=$ 35), and lowest in spring 2009 (8.00 \pm $0.52 \%, \mathrm{n}=35$ ). Among repeatedly sampled anemones, there was a significant drop in the MI of zoochlorellae from summer to spring (repeated measures ANOVA, $\mathrm{p}=0.04, \mathrm{n}=17$ ).

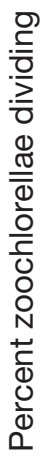

The MI of zooxanthellae in anemone tentacles remained below $1 \%$ in all seasons, with no significant patterns evident among microhabitats (Fig. 4d-f). Because sample sizes were low, this allowed for limited power to examine patterns in summer 2008 and spring 2009 ( $\mathrm{n}=8$ in each season), and no comparisons were possible in fall $2008(\mathrm{n}=1)$.

\section{Stable isotope analysis}

Symbiotic algae showed greater variation in $\delta^{13} \mathrm{C}$ values than mussel or anemone tentacle tissue, both between summer 2008 and spring 2009 and within a season (Fig. 5). The $\delta^{13} \mathrm{C}$ values of zoochlorellate and mixed zoochlorellate anemone tentacles were intermediate between the $\delta^{13} \mathrm{C}$ values of their zoochlorel-

Zoochlorellae
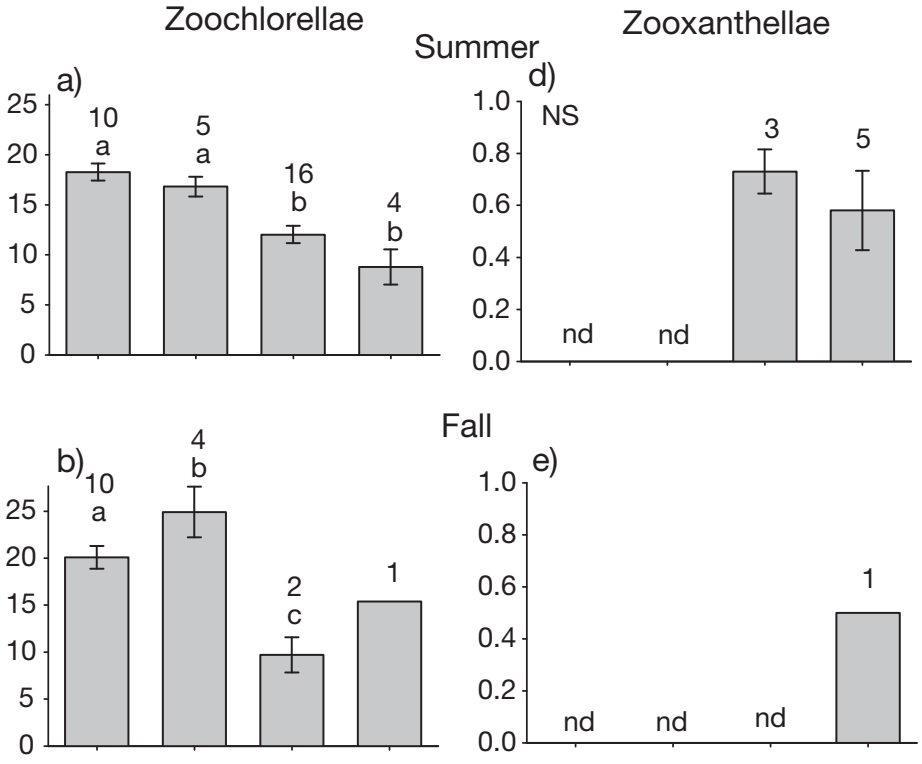

Fall

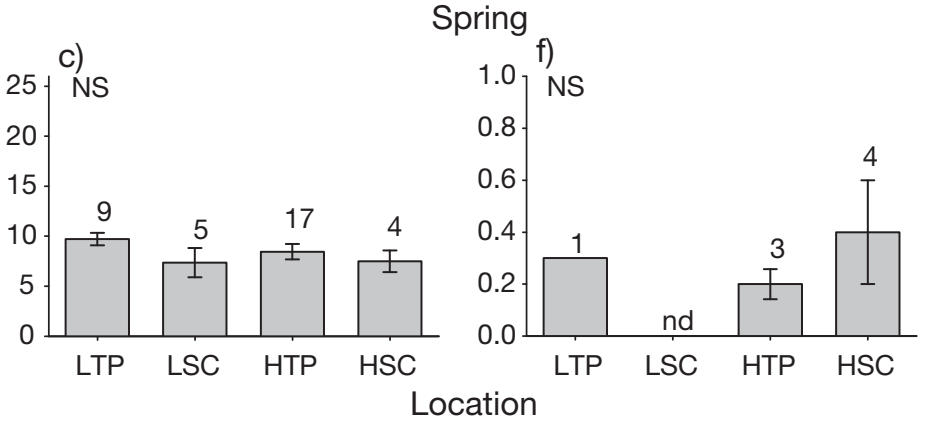

Fig. 4. Seasonal mitotic index $( \pm \mathrm{SE})$ of $(\mathrm{a}-\mathrm{c})$ zoochlorellae and $(\mathrm{d}-\mathrm{f})$ zooxanthellae in Anthopleura xanthogrammica tentacles from low tidepool (LTP), low surge channel (LSC), high tidepool (HTP), and high surge channel (HSC) microhabitats. Numbers above bars indicate sample size; different letters within a season and symbiont type indicate significant difference between microhabitats at $p<0.05$. nd: no data; NS: no significant difference between any microhabitat within a season 


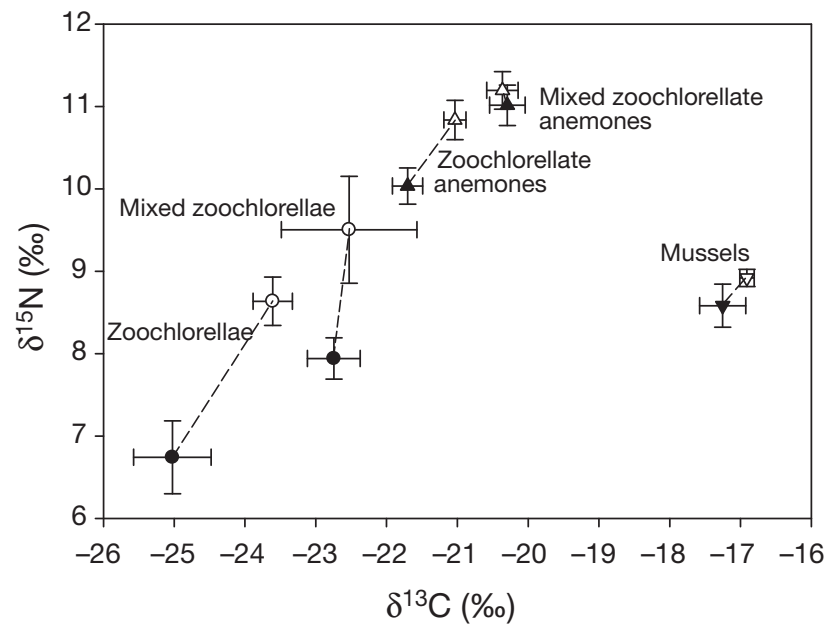

Fig. 5. Mean $( \pm \mathrm{SE}) \delta^{13} \mathrm{C}$ and $\delta^{15} \mathrm{~N}$ isotopic values for zoochlorellate ( $\geq 90 \%$ zoochlorellae) and mixed zoochlorellate (50-90\% zoochlorellae) Anthopleura xanthogrammica tentacle tissue, isolated symbionts composed of zoochlorellae ( $\geq 90 \%$ zoochlorellae), and mixed zoochlorellae (50-90\% zoochlorellae) assemblages, and tissue from Mytilus californianus mussels. Dashed lines connect summer values (dark symbols) to spring values (open symbols). Sample sizes are listed in Table 1

lae and mixed zoochlorellae populations and those of mussels (Fig. 5). Zoochlorellae had the most negative $\delta^{13} \mathrm{C}$ values, averaging $-25.02 \pm 0.55 \%$ in summer and $-23.61 \pm 0.28 \%$ in spring (Table 1 ). Mixed zoochlorellae samples had $\delta^{13} \mathrm{C}$ values of $-22.74 \pm$ $0.38 \%$ in summer and $-22.53 \pm 0.96 \%$ in spring. Mussel tissue $\delta^{13} \mathrm{C}$ was comparatively higher than both of these algal populations, averaging $-17.25 \pm$ $0.32 \%$ in summer and $-16.91 \pm 0.10 \%$ in spring.
The Isoerror dietary mixing model (Phillips \& Gregg 2001) showed that for both summer 2008 and spring 2009, zoochlorellae and mixed zoochlorellae provided more carbon to the host anemone than mussels. Zoochlorellae and mixed zoochlorellae each provided around $62 \pm 5-7 \%$ of anemone carbon in summer 2008 , and nearly $70 \pm 4-12 \%$ of anemone carbon in spring 2009 (Table 2). The isotopic values of zooxanthellate and mixed zooxanthellate anemone tissues $(n=18)$ were not distinguishable from those of isolated algae ( $\mathrm{n}=8)$, as indicated by the considerable overlap between the $\delta^{15} \mathrm{~N}$ of isolated symbionts and host tissues, and these values (Table 1) were excluded from dietary analysis.

\section{DISCUSSION}

Overall, anemones host high densities of zoochlorellae in the relatively cool climate of Slip Point, and these symbionts are energetically important contributors to the association. We found that zoochlorellae were the dominant symbionts in upper intertidal tidepools and in the lower intertidal zone, and that relatively high temperatures likely limit the density of zoochlorellae in upper intertidal surge channels. Although we hypothesized that Anthopleura xanthogrammica derives most of its nutrition from heterotrophic feeding, the contribution of zoochlorellae was greater than that of heterotrophy.

The high surge channel microhabitat was a stressful environment for zoochlorellae, with comparatively extreme temperatures and increased irradi-

Table 1. Mean ( \pm SE) $\delta^{13} \mathrm{C}$ and $\delta^{15} \mathrm{~N}(\%)$ values for Anthopleura xanthogrammica tentacle tissues isolated from hosts of varying symbiont composition, grouped as zoochlorellate ( $\geq 90 \%$ zoochlorellae $\mathrm{mg}^{-1}$ anemone tentacle protein), mixed zoochlorellate (50-90\% zoochlorellae), mixed zooxanthellate (10-50\% zoochlorellae), and zooxanthellate ( $\leq 10 \%$ zoochlorellae), isolated symbionts, and tissue from Mytilus californianus mussels. Summer samples collected 30 to 31 July 2008; spring samples collected 10 to 11 April 2009. $\mathrm{n}=$ sample size

\begin{tabular}{|c|c|c|c|c|c|c|}
\hline & \multicolumn{2}{|c|}{$-\delta^{13} \mathrm{C}(\%)$} & \multicolumn{2}{|c|}{$\longrightarrow \delta^{15} \mathrm{~N}(\%)$} & \multirow{2}{*}{$\overline{\text { Summer }}$} & 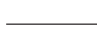 \\
\hline & Summer & Spring & Summer & Spring & & Spring \\
\hline \multicolumn{7}{|l|}{ Anemone } \\
\hline Zoochlorellate & $-21.70 \pm 0.21$ & $-21.04 \pm 0.16$ & $10.03 \pm 0.22$ & $10.84 \pm 0.24$ & 20 & 26 \\
\hline Mixed zoochlorellate & $-20.29 \pm 0.25$ & $-20.36 \pm 0.22$ & $11.02 \pm 0.25$ & $11.20 \pm 0.23$ & 7 & 7 \\
\hline Mixed zooxanthellate & $-19.14 \pm 0.20$ & $-18.99 \pm 0.16$ & $10.83 \pm 0.27$ & $11.18 \pm 0.58$ & 6 & 4 \\
\hline Zooxanthellate & $-18.85 \pm 0.44$ & $-19.12 \pm 0.24$ & $10.88 \pm 0.16$ & $10.95 \pm 0.26$ & 3 & 5 \\
\hline \multicolumn{7}{|l|}{ Algae } \\
\hline Zoochlorellae & $-25.02 \pm 0.55$ & $-23.61 \pm 0.28$ & $6.74 \pm 0.44$ & $8.64 \pm 0.29$ & 13 & 14 \\
\hline Mixed zoochlorellae & $-22.74 \pm 0.38$ & $-22.53 \pm 0.96$ & $7.94 \pm 0.25$ & $9.50 \pm 0.65$ & 3 & 3 \\
\hline Mixed zooxanthellae & $-19.10 \pm 0.09$ & $-19.07 \pm 0.13$ & $10.67 \pm 0.05$ & $11.57 \pm 0.31$ & 2 & 3 \\
\hline Zooxanthellae & -8.99 & $-19.51 \pm 0.40$ & 9.77 & $10.91 \pm 0.16$ & 1 & 2 \\
\hline Mussel & $-17.25 \pm 0.32$ & $-16.91 \pm 0.10$ & $8.58 \pm 0.26$ & $8.92 \pm 0.10$ & 8 & 10 \\
\hline
\end{tabular}


Table 2. Relative percent contribution $( \pm$ SE) of symbiotic zoochlorellae or mixed zoochlorellae and Mytilus californianus to Anthopleura xanthogrammica diet. Carbon isotope fractionation is assumed to be $0.4 \%$ per trophic level (McCutchan et al. 2003)

\begin{tabular}{|lccccc|}
\hline \multirow{2}{*}{ Anemone } & \multicolumn{3}{c}{ Summer } & & \multicolumn{2}{c|}{ Spring } \\
\cline { 2 - 3 } & $\begin{array}{c}\text { Symbiotic } \\
\text { algae }\end{array}$ & $\begin{array}{c}\text { M. califor- } \\
\text { nianus }\end{array}$ & & $\begin{array}{c}\text { Symbiotic } \\
\text { algae }\end{array}$ & $\begin{array}{c}\text { M. califor- } \\
\text { nianus }\end{array}$ \\
\hline Zoochlorellate & $62 \pm 5$ & $38 \pm 5$ & & $68 \pm 4$ & $32 \pm 4$ \\
Mixed zoochlorellate & $63 \pm 7$ & $37 \pm 7$ & & $69 \pm 12$ & $31 \pm 12$ \\
\hline
\end{tabular}

Differences in anemone physiology and behavior in different microhabitats may also influence the distribution and density of symbionts. During emersion, continuously submerged tidepool anemones tend to remain open and expanded (M. R. Levine pers. obs.), a behavior seen in moderate (but not high) light with Anthopleura elegantissima (Pearse 1974), while surge channel anemones con-

ance likely leading to the observed lower density of zoochlorellae in summer and spring. Although a similar trend was evident in fall, this pattern was not statistically supported, an outcome likely due to low sampling (and statistical power) in this season. High microhabitat temperatures could cause a reduction in zoochlorellae density in a number of ways, 2 of which are discussed. First, the growth rate of zoochlorellae may be reduced. In both Anthopleura xanthogrammica and A. elegantissima, MI of zoochlorellae decreases over time periods of 20 to $25 \mathrm{~d}$ when anemones are maintained at $20^{\circ} \mathrm{C}\left(\mathrm{O}^{\prime}\right.$ Brien \& Wyttenbach 1980, Saunders \& Muller-Parker 1997), and remains unchanged in $A$. elegantissima over shorter time periods of 1 to $4 \mathrm{~d}$ exposure to a broad range of experimental temperatures up to $24^{\circ} \mathrm{C}$ (Verde \& McCloskey 2001, 2007). However, the MI of zoochlorellae was not significantly lower in tentacles from anemones in the high surge channel than in tentacles from anemones in the high tidepool. If sustained exposure to elevated temperature is required to decrease the MI (as in O'Brien \& Wyttenbach 1980 and Saunders \& Muller-Parker 1997), the daily low-tide exposures experienced at Slip Point may not be sufficiently long to initiate a differential decline in MI between the high surge channel and other microhabitats. Second, preferential expulsion of dividing algae may result in a greater loss of zoochlorellae than of zooxanthellae. A greater loss of zoochlorellae is possible because the MI of zoochlorellae was approximately 10 to 20 times greater than that of zooxanthellae, and McCloskey et al. (1996) showed that the MI of expelled zoochlorellae and zooxanthellae from Anthopleura elegantissima was 3.5 and 4.2 times greater, respectively, than that of symbionts isolated from the host. In addition, the rate of expulsion of dividing cells may increase with temperature (Baghdasarian \& Muscatine 2000). Greater algal expulsion in the warmer high surge channel environment than in the high tidepool, combined with preferential expulsion of dividing cells, could explain the reduced densities of zoochlorellae observed in this microhabitat. tracted to varying degrees, with far fewer tentacles exposed to the environment. A contracted state lowers anemone oxygen demand and metabolic rate as compared to the expanded state of submerged individuals, and considerably reduces photosynthesis due to shading of algal symbionts (Shick \& Dykens 1984, Zamer \& Shick 1987). Surge channel anemones also covered their body column with small rocks and shell fragments, a behavior that also effectively lowers the irradiance reaching the symbionts (Pearse \& Muscatine 1971, Pearse 1974, Dykens \& Shick 1984, Shick \& Dykens 1984).

The observed distribution of zoochlorellae and zooxanthellae in Anthopleura xanthogrammica in the low intertidal zone at Slip Point is consistent with that observed in other studies. Kitaeff (2007) found that low intertidal $A$. xanthogrammica tentacles in Coos Bay, Oregon $\left(44^{\circ} \mathrm{N}\right)$, contained a much higher proportion of zoochlorellae than zooxanthellae. Similarly, in Bamfield, British Columbia, Canada $\left(48^{\circ} \mathrm{N}\right)$, low tidepools and crevices hosted predominantly zoochlorellate $A$. xanthogrammica tentacles (Bates 2000). The prevalence of zoochlorellate A. xanthogrammica tentacles in high shore tidepools at Slip Point is consistent with results obtained at Tatoosh Island (48 $8^{\circ}$, approximately $30 \mathrm{~km}$ NW of Slip Point), where high intertidal $A$. xanthogrammica tentacles contained primarily zoochlorellae irrespective of microhabitat (Secord \& Augustine 2000). In contrast, Bates (2000) found an increasing proportion of zooxanthellae in tidepool A. xanthogrammica tentacles as compared with crevice A. xanthogrammica tentacles at the same shore height. These differing upper intertidal symbiont distribution patterns may be explained by differences in thermal conditions during exposure to air at these study sites. Just as relatively cool microhabitats at Slip Point support a higher proportion of zoochlorellae in A. xanthogrammica, relatively cool study sites (including Tatoosh Island; Helmuth et al. 2002) may support zoochlorellae as symbionts of $A$. xanthogrammica to a greater extent than relatively warm sites. 
Despite the greater than $25^{\circ} \mathrm{C}$ annual range in air temperatures recorded during the study period, algal density varied seasonally in zoochlorellate anemone tentacles in only a few instances. During the comparatively warm summer season, densities of zoochlorellae were lower in the high tidepool than in the low tidepool, while during the cooler fall and spring seasons, no significant differences existed between high and low intertidal pools. It is likely that warmer seasonal temperatures experienced during tidepool emersion caused this relative decline in zoochlorellae density, as the high intertidal pool was emersed for approximately $45 \%$ more time annually (as judged by the Clallam Bay tide datum). There was also a trend towards lower densities of zoochlorellae in low tidepool and low surge channel anemone tentacles, likely driven by the significantly reduced MI of zoochlorellae in spring as compared to summer. Although zoochlorellae are comparatively better suited to low irradiance conditions than zooxanthellae (Saunders \& Muller-Parker 1997, Verde \& McCloskey 2001, 2002, 2007), wintertime ambient irradiance levels in the low intertidal at Slip Point may not be sufficient to maintain growth rates above expulsion rates, hindering the ability of Anthopleura xanthogrammica to maintain seasonally stable densities. With these exceptions, little seasonal change was evident in the relative proportions of zoochlorellae and zooxanthellae in A. xanthogrammica tentacles, and the results of this study generally support the seasonal stability in algal symbionts observed for A. elegantissima from Puget Sound, Washington (Bergschneider \& Muller-Parker 2008, Dimond et al. 2011).

Tidepool temperatures did not exceed $24.4^{\circ} \mathrm{C}$ and surge channel temperatures did not exceed $30.6^{\circ} \mathrm{C}$ at Slip Point, suggesting a generally cool microclimate at this site. In comparison, tidepool temperatures as high as $31^{\circ} \mathrm{C}$ were measured in the San Juan Islands in the Puget Sound region (Jensen \& Muller-Parker 1994) and as high as $26^{\circ} \mathrm{C}$ along the outer coast of Vancouver Island (Bates 2000), suggesting that there are strong regional differences in microclimates that influence tidepools in the Pacific Northwest. Although other studies have not measured ambient temperatures in surge channels, temperature loggers mimicking exposed rocks on Tatoosh Island have recorded temperatures between 35 and $41.5^{\circ} \mathrm{C}$ during summer low tides (Harley \& Helmuth 2003). Our study suggests that surge channel temperatures will be much higher than those in tidepools during extreme heat events at Slip Point, further restricting the abundance of zoochlorellae in this microhabitat.
It is important to note that temperature patterns in this study were measured in only 2 locations at Slip Point, and therefore the conclusion that the high surge channel is the more variable thermal microhabitat annually is based on limited observations. Despite this limitation, the temperature record obtained is likely a good approximation of microhabitat variability within the upper intertidal zone of Slip Point. The increased thermal variability recorded in the surge channel was not likely due to differences in emersion time between microhabitats. The vertical tidal height of the tidepool data logger was $0.4 \mathrm{~m}$ greater than that of the surge channel, so a temperature pattern driven purely by emersion time would instead favor more extreme tidepool temperatures. Although intertidal temperature differences may result from substratum angle (Helmuth \& Hofmann 2001), this is also unlikely to be driving the observed pattern, as both data loggers were placed on surfaces that were nearly horizontal. In addition, the nearby surge channel wall shaded the surge channel data logger. All of these factors would have contributed to a conservative estimate of air temperatures in this microhabitat, minimizing observed differences. However, the tidepool selected for temperature monitoring may have provided more moderate temperatures than other nearby pools due to its comparatively large size. Although of similar depth and width as many other tidepools located at the same shore height, it was of greater length. Because lower tidepools and surge channels are emersed for only between 1 and $20 \%$ of time on an annual basis at Slip Point (as estimated by the Clallam Bay tide datum), temperature differences between lower intertidal microhabitats are likely to be comparatively minor and short-lived.

The actual temperatures experienced by anemones living in these environments may not be represented accurately by data loggers. Submerged ectothermic organisms have body temperatures that are very close to the surrounding water temperature (Helmuth 1998), while in air these organisms have body temperatures determined by environmental factors such as air temperature, wave splash, solar radiation, and wind speed, among other factors (Porter \& Gates 1969, Helmuth 1998, Gilman et al. 2006, Helmuth et al. 2006). Behavioral factors are also important; anemones are able to evaporatively cool themselves by releasing water from their gastrovascular cavity (Shick 1991). In Anthopleura elegantissima, larger individuals can remain at temperatures well below warm ambient temperatures, while smaller individuals heat quickly as they exhaust their gastrovascular 
water supply (Bingham et al. 2011). This cooling ability is likely to be even more pronounced in A. xanthogrammica due to its comparatively large body size. It is also possible that actual anemone temperatures do not differ greatly from recorded surge channel temperatures. Kitaeff (2007) found that A. xanthogrammica internal body temperatures generally were within $3^{\circ} \mathrm{C}$ of the maximum recorded air temperatures during aerial exposure in summer in Sitka, Alaska.

Stable isotope signatures of anemone tentacles suggest that Anthopleura xanthogrammica containing primarily zoochlorellae derive most of their dietary carbon ( 62-70\%) from zoochlorellae and only a minor fraction from feeding on Mytilus californianus mussels $(\sim 31-38 \%)$. Although a number of uncertainties in the application of stable isotopes to this symbiosis are discussed, the size of the estimated symbiotic contribution is sufficiently great to establish zoochlorellae as an important nutritional source to their host anemones.

The use of tentacles in the analysis may have contributed to the high contributions of zoochlorellae, because nutritional contributions were estimated for a body region where they are potentially greatest: zoochlorellae are at least twice as dense in the crown and tentacle regions as in the mid and base body regions of Anthopleura xanthogrammica (Kitaeff 2007). Future study with whole or partitioned A. xanthogrammica anemones is needed to determine whether tentacles overestimate the amount of algal carbon provided to the host, and whether symbiotic contributions vary with symbiont density.

Although the heterotrophic diet of Anthopleura xanthogrammica was only represented by 1 prey item (Mytilus californianus), this organism represents $70 \%$ of this anemone's diet (Dayton 1973, Sebens 1981). Even if anemones at Slip Point consume a greater proportion of other invertebrates, the estimated contribution of heterotrophy would not change substantially. Dayton (1973) found that the barnacle Semibalanus cariosus accounted for approximately $18 \%$ of A. xanthogrammica prey (together, the contribution of $M$. californianus and S. cariosus was nearly $90 \%$ ). A study on the Olympic Peninsula found little difference between the $\delta^{13} \mathrm{C}$ values of $M$. californianus and S. cariosus (-15.67\%o and $-15.79 \%$, respectively; Tallis 2009 ).

Algal symbionts may also receive carbon and nitrogen from their host, leading to host and symbiont stable isotope values becoming closer and resulting in overestimates of symbiont contributions in the Isoerror mixing model (Phillips \& Gregg 2001). Nitrogen recycling may result from ammonium $\left(\mathrm{NH}_{4}^{+}\right)$waste from the host being incorporated into organic compounds by the symbionts, and then translocated back to the host (Muscatine 1980). Although not measured for Anthopleura xanthogrammica, the large amounts of $\mathrm{NH}_{4}{ }^{+}$released by $A$. elegantissima in tidepools suggest that nitrogen recycling is limited (Jensen \& Muller-Parker 1994). Carbon conservation may also occur, with symbionts receiving $\mathrm{CO}_{2}$ from host respiration (Bergschneider \& Muller-Parker 2008). In this case, the $\delta^{13} \mathrm{C}$ of the host-derived $\mathrm{CO}_{2}$ will resemble host $\delta^{13} \mathrm{C}$ (Muscatine et al. 1989), shifting the observed symbiont $\delta^{13} \mathrm{C}$ values towards host values and overestimating the carbon contribution (= carbon isotope similarity) of symbionts to the host.

The stable isotope results suggest that zoochlorellae contribute nutritionally to Anthopleura xanthogrammica to a greater extent than in A. elegantissima (Engebretson \& Muller-Parker 1999, Verde \& McCloskey 2001，2002，2007, Bergschneider \& Muller-Parker 2008). This result is surprising given the large body size of this species. Possibly, differences in morphology may allow A. xanthogrammica to provide zoochlorellae (versus zooxanthellae) with more favorable temperature and light regimes. A. xanthogrammica has considerably thicker body tissues that attenuate approximately $57 \%$ more light than those of $A$. elegantissima, resulting in a comparatively favorable environment for zoochlorellae (Dimond et al. 2012). As compared to A. elegantissima, A. xanthogrammica may favor greater symbiont shading (via thicker body tissues) and cooler body temperatures (via greater gastrovascular water volume), creating a cooler, lower light microclimate for the symbiotic algae. This is supported by microzonation within $A$. xanthogrammica reported by Kitaeff (2007), who found mixed A. xanthogrammica containing zooxanthellae in the tentacles and crown region, and zoochlorellae (alone or mixed) in the mid and base regions, mirroring the overall 'low temperature, low light' intertidal distribution of zoochlorellae (Bates 2000, Secord \& Augustine 2000, Kitaeff 2007).

Anthopleura xanthogrammica appears to be an intrinsically more suitable host for zoochlorellae than A. elegantissima. Bates et al. (2010) compared A. xanthogrammica and A. elegantissima of similar sizes that co-occurred in tidepools and rock crevices and found that more than $95 \%$ of A. elegantissima individuals contained primarily zooxanthellae, while $55 \%$ of $A$. xanthogrammica individuals contained primarily zoochlorellae. It is possible that the relatively high nutritional contributions of zoochlorellae 
observed in the present study are typical for the A. xanthogrammica symbiosis. Future studies directly comparing the algal productivity and carbon translocation of zoochlorellate A. xanthogrammica and A. elegantissima are needed to resolve this question. Similarly, further research with populations of A. xanthogrammica hosting a more balanced proportion of zoochlorellae and zooxanthellae, if these exist, is needed to test the relative contributions of each algal symbiont to host nutrition.

Hypothesized ecological responses to predicted global warming include poleward shifts in the latitudinal ranges of species (Barry et al. 1995, Southward et al. 1995, Sagarin et al. 1999, Parmesan et al. 2005) and localized extinction in 'hotspots' caused by the interaction of mid-day summer low tides and increasingly extreme temperatures (Helmuth et al. 2002). It is likely that many unexpected responses will also occur. For example, warm-water species of Portuguese macroalgae have expanded poleward as expected during the previous $50 \mathrm{yr}$ warming period, but cold-water species have shifted equally northward and southward (Lima et al. 2007). Because distributions of zooxanthellae and zoochlorellae in Anthopleura xanthogrammica are related to thermal differences within the intertidal zone and show only minimal response to seasonal temperature patterns, changes in symbiont type within A. xanthogrammica (at both regional and local scales) may indicate any of these dynamics. Where A. xanthogrammica populations contain both zooxanthellae and zoochlorellae (from $\sim 38^{\circ}$ to at least $48^{\circ} \mathrm{N}_{\text {; }}$ Bates 2000, Secord \& Augustine 2000, Kitaeff 2007), annual or decadal monitoring of symbiont type and distributions in tentacles from anemone populations in surge channels at the upper intertidal extent of anemone occurrence may be sufficient to assess any changes in symbiont distributions, and would be easy to integrate into a larger study of changes in species distribution. Focused sampling to determine the relative distribution of zooxanthellae and zoochlorellae in tentacles of high surge channel anemones may be the most rapid way to judge biological response in this algal-anemone symbiosis, as this microhabitat experiences comparatively greater temperature extremes than tidepools and the anemones are more likely to contain mixed populations of zooxanthellae and zoochlorellae. Because of their broad thermal tolerance (Muller-Parker et al. 2006), zooxanthellae are predicted to replace zoochlorellae in locations subjected to chronic increases in temperature due to global warming (Secord \& Augustine 2000, Verde \& McCloskey 2007).
Acknowledgements. We thank B. Bingham for statistical advice and D. Donovan for thoughtful comments on this research, which was completed in partial fulfillment of M.R.L.'s M.S. degree requirements at Western Washington University. The helpful comments of 2 anonymous reviewers improved this manuscript. G. Headley, J. Dimond, J. Conrad, I. Freytes, A. Fletcher, R. Allee, T. Ritchie, and M. Parker provided field assistance, and N. Schwarck, G. McKeen, J. Apple and the Western Washington University Biology stockroom staff provided technical assistance. Funding was provided by grants from the National Science Foundation (NSF IOS 0822179), Western Washington University Fund for the Enhancement of Graduate Research, and a Sigma Xi Grant-in-Aid of Research. Field samples were collected in accordance with Washington State Scientific Collection Permit no. 08-078A. This work took place while G.M.P. served in a position at the National Science Foundation. Any opinion, findings, and conclusions or recommendations expressed in this material are those of the authors and do not necessarily reflect the view of the National Science Foundation.

\section{LITERATURE CITED}

Baghdasarian G, Muscatine L (2000) Preferential expulsion of dividing algal cells as a mechanism for regulating algal-cnidarian symbiosis. Biol Bull (Woods Hole) 199: 278-286

Barry J, Baxter C, Sagarin R, Gilman S (1995) Climaterelated, long-term faunal changes in a California rocky intertidal community. Science 267:672-675

Bates A (2000) The intertidal distribution of two algal symbionts hosted by Anthopleura xanthogrammica (Brandt 1835). J Exp Mar Biol Ecol 249:249-262

Bates AE, McLean L, Laing P, Raeburn LA, Hare C (2010) Distribution patterns of zoochlorellae and zooxanthellae hosted by two Pacific northeast anemones, Anthopleura elegantissima and A. xanthogrammica. Biol Bull 218: 237-247

Bergschneider H, Muller-Parker G (2008) Nutritional role of two algal symbionts in the temperate sea anemone $A n$ thopleura elegantissima Brandt. Biol Bull (Woods Hole) 215:73-88

Bingham B, Freytes I, Emery M, Dimond J, Muller-Parker G (2011) Aerial exposure and body temperature of the intertidal sea anemone Anthopleura elegantissima. Invertebr Biol 130:291-301

Dayton P (1973) Two cases of resource partitioning in an intertidal community: making the right prediction for the wrong reason. Am Nat 107:662-670

Dimond J, Bingham B, Muller-Parker G, Wuesthoff K, Francis L (2011) Seasonal stability of a flexible algalcnidarian symbiosis in a highly variable temperate environment. Limnol Oceanogr 56:2233-2242

Dimond J, Holzman B, Bingham B (2012) Thicker host tissues moderate light stress in a cnidarian endosymbiont. $\mathrm{J}$ Exp Biol, in press

> Dykens J, Shick J (1984) Photobiology of the symbiotic sea anemone, Anthopleura elegantissima: defenses against photodynamic effects, and seasonal photoacclimatization. Biol Bull (Woods Hole) 167:683-697

Engebretson H, Muller-Parker G (1999) Translocation of photosynthetic carbon from two algal symbionts to the sea anemone Anthopleura elegantissima. Biol Bull 
(Woods Hole) 197:72-81

Gilman S, Wethey D, Helmuth B (2006) Variation in the sensitivity of organismal body temperature to climate change over local and geographic scales. Proc Natl Acad Sci USA 103:9560-9565

Gorokhova E, Hansson S (1999) An experimental study on variations in stable carbon and nitrogen isotope fractionation during growth of Mysis mixta and Neomysis integer. Can J Fish Aquat Sci 56:2203-2210

Hand C (1955) The sea anemones of central California. Part II. The endomyarian and mesomyarian anemones. Wasmann J Biol 13:37-97

> Harley C, Helmuth B (2003) Local- and regional-scale effects of wave exposure, thermal stress, and absolute vs. effective shore level on patterns of intertidal zonation. Limnol Oceanogr 48:1498-1508

> Helmuth B (1998) Intertidal mussel microclimates: predicting the body temperature of a sessile invertebrate. Ecol Monogr 68:51-74

> Helmuth B, Hofmann G (2001) Microhabitats, thermal heterogeneity, and patterns of physiological stress in the rocky intertidal zone. Biol Bull (Woods Hole) 201: 374-384

Helmuth B, Harley C, Halpin P, O'Donnell M, Hofmann G, Blanchette C (2002) Climate change and latitudinal patterns of intertidal thermal stress. Science 298:1015-1017

> Helmuth B, Broitman B, Blanchette C, Gilman S and others (2006) Mosaic patterns of thermal stress in the rocky intertidal zone: implications for climate change. Ecol Monogr 76:461-479

Jensen S, Muller-Parker G (1994) Inorganic nutrient fluxes in anemone-dominated tide pools. Pac Sci 48:32-43

Kitaeff P (2007) Latitudinal differences in the distribution of two algal symbionts within the intertidal sea anemone, Anthopleura xanthogrammica. MS thesis, Western Washington University, Bellingham, WA

Lajeunesse T, Trench R (2000) Biogeography of two species of Symbiodinium (Freudenthal) inhabiting the intertidal sea anemone Anthopluera elegantissima (Brandt). Biol Bull (Woods Hole) 199:126-134

> Letsch M, Muller-Parker G, Friedl T, Lewis L (2009) Elliptochloris marina sp. nov. (Trebouxiophyceae, Chlorophyta), symbiotic green alga of the temperate Pacific sea anemones Anthopleura xanthogrammica and A. elegantissima (Anthozoa, Cnidaria). J Phycol 45:1127-1135

Lima F, Ribeiro P, Queiroz N, Hawkins S, Santos A (2007) Do distributional shifts of northern and southern species of algae match the warming pattern? Glob Change Biol 13:2592-2604

Lowry O, Rosenbrough N, Farr H, Randall R (1951) Protein measurement with the Folin phenol reagent. J Biol Chem 193:265-275

> McCloskey L, Cove T, Verde E (1996) Symbiont expulsion from the anemone Anthopleura elegantissima (Brandt) (Cnidaria: Anthozoa). J Exp Mar Biol Ecol 195:173-186

McCutchan JJ, Lewis WJ, Kendall C, McGrath C (2003) Variation in trophic shift for stable isotope ratios of carbon, nitrogen, and sulfur. Oikos 102:378-390

Muller-Parker G, Pierce-Cravens GJ, Bingham BL (2006) Broad thermal tolerance of the symbiotic dinoflagellate Symbiodinium muscatinei (Dinophyta) in the sea anemone Anthopleura elegantissima (Cnidaria) from northern latitudes. J Phycol 43:25-31

Muscatine L (1980) Uptake, retention, and release of dissolved inorganic nutrients by marine algae-invertebrate associations. In: Cook CB, Pappas PW, Rudolph ED (eds) Cellular interactions in symbiosis and parasitism. Ohio State University, Columbus, OH, p 229-244

Muscatine L, Porter J, Kaplin I (1989) Resource partitioning by reef corals as determined from stable isotope composition. 1. $\delta^{13} \mathrm{C}$ of zooxanthellae and animal tissue vs depth. Mar Biol 100:185-193

> O'Brien T, Wyttenbach C (1980) Some effects of temperature on the symbiotic association between zoochlorellae (Chlorophyceae) and the sea anemone Anthopleura xanthogrammica. Trans Am Microsc Soc 99:221-225

> Parmesan C, Gaines S, Gonzales L, Kaufman D, Kingsolver J, Townsend Peterson A, Sagarin R (2005) Empirical perspectives on species borders: from traditional biogeography to global change. Oikos 108:58-75

Pearse V (1974) Modification of sea anemone behavior by symbiotic zooxanthellae: expansion and contraction. Biol Bull (Woods Hole) 147:641-651

Pearse V, Muscatine L (1971) Role of symbiotic algae (zooxanthellae) in coral calcification. Biol Bull (Woods Hole) 141:350-363

> Peterson B, Fry B (1987) Stable isotopes in ecosystem studies. Annu Rev Ecol Evol Syst 18:293-320

Phillips D, Gregg J (2001) Uncertainty in source partitioning using stable isotopes. Oecologia 127:171-179

Pitt K, Connolly R, Meziane T (2009) Stable isotope and fatty acid tracers in energy and nutrient studies of jellyfish: a review. Hydrobiologia 616:119-132

Porter W, Gates D (1969) Thermodynamic equilibria of animals with environment. Ecol Monogr 39:227-244

- Sagarin R, Barry J, Gilman S, Baxter C (1999) Climaterelated changes in an intertidal community over short and long time scales. Ecol Monogr 69:465-490

Saunders B, Muller-Parker G (1997) The effects of temperature and light on two algal populations in the temperate sea anemone Anthopleura elegantissima (Brandt, 1835). J Exp Mar Biol Ecol 211:213-224

Sebens K (1981) The allometry of feeding, energetics, and body size in three sea anemones. Biol Bull (Woods Hole) 161:152-171

Sebens K (1983) Population dynamics and habitat suitability of the intertidal sea anemones Anthopleura elegantissima and A. xanthogrammica. Ecol Monogr 53: 405-433

> Secord D, Augustine L (2000) Biogeography and microhabitat variation in temperate algal-invertebrate symbioses: zooxanthellae and zoochlorellae in two pacific intertidal sea anemones, Anthopleura elegantissima and A. xanthogrammica. Invertebr Biol 119:139-146

Shick J (1991) A functional biology of sea anemones, Vol 1. Chapman \& Hall, London

Shick J, Dykens J (1984) Photobiology of the symbiotic sea anemone Anthopleura elegantissima: photosynthesis, respiration and behavior under intertidal conditions. Biol Bull (Woods Hole) 166:608-619

Sokal R, Rohlf J (1969) Introduction to biostatistics, Vol 1. W.H. Freeman and Company, New York, NY

> Southward A, Hawkins S, Burrows M (1995) Seventy years' observations of changes in distribution and abundance of zooplankton and intertidal organisms in the western English Channel in relation to rising sea temperature. J Therm Biol 20:127-155

$>$ Tallis H (2009) Kelp and rivers subsidize rocky intertidal communities in the Pacific Northwest (USA). Mar Ecol Prog Ser 389:85-96 
Underwood A (1981) Techniques of analysis of variance in experimental marine biology and ecology. Oceanogr Mar Biol Annu Rev 19:513-605

Verde E, McCloskey L (1996) Photosynthesis and respiration of two species of algal symbionts in the anemone Anthopleura elegantissima (Brandt) (Cnidaria; Anthozoa). J Exp Mar Biol Ecol 195:187-202

> Verde E, McCloskey L (2001) A comparative analysis of the photobiology of zooxanthellae and zoochlorellae symbiotic with the temperate clonal anemone Anthopleura elegantissima (Brandt). I. Effect of temperature. Mar Biol 138:477-489

Verde E, McCloskey L (2002) A comparative analysis of the

Editorial responsibility: Brian Helmuth, Columbia, South Carolina, USA photobiology of zooxanthellae and zoochlorellae symbiotic with the temperate clonal anemone Anthopleura elegantissima (Brandt). II. Effect of light intensity. Mar Biol 141:225-239

Verde E, McCloskey L (2007) A comparative analysis of the photobiology of zooxanthellae and zoochlorellae symbiotic with the temperate clonal anemone Anthopleura elegantissima (Brandt). III. Seasonal effects of natural light and temperature on photosynthesis and respiration. Mar Biol 152:775-792

Zamer W, Shick J (1987) Physiological energetics of the intertidal sea anemone Anthopleura elegantissima. II. Energy balance. Mar Biol 93:481-491

Submitted: September 1, 2010; Accepted: January 13, 2012 Proofs received from author(s): April 24, 2012 